\title{
Status of Micronutrients in Different Districts of Odisha, India
}

\author{
Aurobindo Mohanta ${ }^{1}$, Sai Parasar Das ${ }^{2 *}$, Gourahari Santra ${ }^{2}$ and Debadatta Sethi $^{3}$ \\ ${ }^{1}$ Department of Agronomy, Institute of Agricultural Sciences, \\ Sikhsha O Anusandhan University, Bhubaneswar, 751003, India \\ ${ }^{2}$ Department of Soil Science and Agricultural Chemistry, Institute of Agricultural Sciences, \\ Sikhsha O Anusandhan University, Bhubaneswar, 751003, India \\ ${ }^{2}$ Department of Soil Science and Agricultural Chemistry, \\ Odisha University of Agriculture and Technology, Bhubaneswar, 751003, India
}

*Corresponding author

\section{A B S T R A C T}

\begin{tabular}{|c|}
\hline Keywords \\
\hline $\begin{array}{l}\text { Micronutrient, } \\
\text { micronutrient } \\
\text { deficiency, status of } \\
\text { micronutrients }\end{array}$ \\
\hline Article Info \\
\hline $\begin{array}{l}\text { Accepted: } \\
22 \text { June } 2020 \\
\text { Available Online: } \\
10 \text { July } 2020\end{array}$ \\
\hline
\end{tabular}

Proper assessment of available micronutrient status in soil is very important as their deficiency and toxicity range in soil is quite narrow. Deficiency of micronutrient may be due to low total content of elements caused by soil factors reducing their availability to plants. The present study was taken up to identify the micronutrients status in soils of different districts of Odisha viz. Angul, Cuttack, Deogarh, Dhenkanal, Khurdha, Puri and Sambalpur. All the soil samples were found to be adequate in Fe content and it was found to be relatively high in coastal districts especially Puri. 66.42 per cent soils were sufficient and 33.57 per cent soils were deficient in $\mathrm{Zn}$ status whereas $80 \%$ soil samples were found to be deficient in available boron. The mean value for $\mathrm{Mn}$ and $\mathrm{Cu}$ ranged from 27.65 to 65.64 and 1.10 to $2.69 \mathrm{mg} \mathrm{kg}^{-1}$ respectively.

\section{Introduction}

The recent stagnation in crop production can be attributed to intensive cropping by adoption of high yielding varieties without recommended application of micronutrients. It is very pertinent to estimate and monitor the micronutrient status / deficiency in agroecological regions to forecast potential micronutrient problem in order to develop models for different soil crop situation. Deficiency of micronutrient may be due to low total content of elements caused by soil factors reducing their availability to plants.

The micronutrients are equally essential for the growth, development and reproduction of plant as major nutrients. These are activators of various enzymes and other physiological processes viz. gene expression, biosynthesis of proteins, nucleic acids, growth substances, chlorophyll and secondary metabolites, metabolism of carbohydrates and lipids, stress tolerance, etc. (Singh, 2004; Rengel, 2007; 
Gao et al., 2008).Due to narrow deficiency and toxicity range in soil proper assessment of micronutrient status is necessary before their supplementation through external sources. In view of the above considerations, the present study was taken upto identify the micronutrients status in soils of different districts of Odisha.

\section{Materials and Methods}

The surface $(0.15 \mathrm{~m})$ soil samples (140 nos.) were collected with the help of GPS from seven districts of Odisha viz. Angul, Cuttack, Deogarh, Dhenkanal, Khurdha, Puri and Sambalpur. The soil samples were processed and passed through $2 \mathrm{~mm}$ sieveand analyzed for the micronutrients ( $\mathrm{Fe}, \mathrm{Mn}, \mathrm{Zn}$ and $\mathrm{Cu}$ ) using DTPA extractantas per the method suggested by Lindsay and Norvell (1978) using atomic absorption spectrophotometer. Soil B was extracted with hot water and estimated using Azomithene $\mathrm{H}$ (Page et al., 1982). All the data were analyzed statistically using the software SPSS (Version 17).

\section{Results and Discussion}

\section{Iron $(\mathbf{F e})$}

The results revealed that DTPA extractable Fe content varied from 132.72-9.44, 118.82$47.48, \quad 110.74-17.80, \quad 284.75-1.84, \quad 169.3-$ 73.04, 197.737-34.43, 76.28-11.68 mg kg-1 with mean value of $49.22,76.97,59.13$, $84.59,98.33,116.60,38.79 \mathrm{mg} \mathrm{kg}^{-1}$ in the soils of Angul, Cuttack, Deogarh, Dhenkanal, Khurdha, Puri and Sambalpur respectively (Table 1).

All the soil samples were found to be adequate in $\mathrm{Fe}$ content considering critical limits of $4.5 \mathrm{mg} \mathrm{kg}^{-1}$. The Fe content was found to be relatively high in coastal district especially Puri which may be attributed to the reduction of $\mathrm{Fe}$ resulting in lower adsorbability in the clay surfaces because of the prolonged moist condition of soil in wetland situation and subsequent release of $\mathrm{Fe}$ in longer submerged condition of soil (Das and Talukdar 2003).

\section{Zinc (Zn)}

The data pertaining to DTPA-extractable Zn in table no. 1 showed that available $\mathrm{Zn}$ content ranged from 1.56- $0.28,3-0.64,1.16-0.12$, 2.72- $0.5,2.46-1.04,2.886-0.36$ and $0.96-$ $0.14 \mathrm{mg} \mathrm{kg}^{-1}$ with a mean value of $0.59,1.43$, $0.51,0.94,1.40,1.33$ and $0.37 \mathrm{mg} \mathrm{kg}^{-1}$ in the soils of Angul, Cuttack, Deogarh, Dhenkanal, Khurdha, Puri and Sambalpur respectively.

Similar reports were also reported by Athokpam et al., (2016) and Khanday et al., 2017. Considering $0.6 \mathrm{mg} \mathrm{kg}^{-1}$ as the critical limit of available $\mathrm{Zn}$ as suggested by (Lindsay and Norvell, 1978), 66.42 per cent were sufficient and 33.57 per cent soils were deficient in $\mathrm{Zn}$ status.

\section{Copper (Cu)}

DTPA-extractable $\mathrm{Cu}$ content in the soils of Angul, Cuttack, Deogarh, Dhenkanal, Khurdha, Puri and Sambalpur ranged from 4.54-0.96, 3.18-1.32, 4.06-0.80, 6.22-0.90, $3.02-2.3,3.941-1.33$ and $3.52-0.3 \mathrm{mg} \mathrm{kg}^{-1}$ respectively. Considering $0.20 \mathrm{mg} \mathrm{Cu} \mathrm{kg}^{-1}$ soil as critical level (Lindsay and Norvell, 1978), all the soils were sufficient with available $\mathrm{Cu}$. Similar findings were also made by Sen et al., 1997, Gupta et al., 2003, Verma et al., 2007, Athokpam et al., 2013, Athokpam et al., 2016 and Athokpam et al., 2018. Highest variation in $\mathrm{Cu}$ was noticed in soils of Dhenkanal with a standard deviation of 1.66. Similar findings were made by Sangwan et al., 1993, Kumar et al., 1996 and Satyavathi and Reddy 2004. 
Table.1 Status of Micronutrients in different districts of Odisha

\begin{tabular}{|c|c|c|c|c|c|c|c|c|c|c|c|c|c|c|c|}
\hline \multirow[t]{2}{*}{ Districts } & \multicolumn{3}{|c|}{ B } & \multicolumn{3}{|c|}{$\mathbf{F e}$} & \multicolumn{3}{|c|}{ Mn } & \multicolumn{3}{|c|}{$\mathbf{C u}$} & \multicolumn{3}{|c|}{$\mathbf{Z n}$} \\
\hline & Range & Mean & SD & Range & Mean & SD & Range & Mean & SD & Range & Mean & SD & Range & Mean & SD \\
\hline Angul & $\begin{array}{l}0.658- \\
0.12\end{array}$ & 0.35 & 0.15 & $\begin{array}{l}132.72- \\
9.44\end{array}$ & 49.22 & 33.43 & $\begin{array}{l}62.84- \\
5.02\end{array}$ & 28.60 & 18.01 & $\begin{array}{l}4.54- \\
0.96\end{array}$ & 2.00 & 0.89 & $\begin{array}{l}1.56- \\
0.28\end{array}$ & 0.59 & 0.33 \\
\hline Cuttack & $\begin{array}{l}0.718- \\
0.2\end{array}$ & 0.37 & 0.13 & $\begin{array}{l}118.82- \\
47.48\end{array}$ & 76.97 & 20.54 & $\begin{array}{l}92.16- \\
27.68\end{array}$ & 57.85 & 18.77 & $\begin{array}{l}3.18- \\
1.32\end{array}$ & 2.00 & 0.43 & $3-0.64$ & 1.43 & 0.65 \\
\hline Deogarh & $\begin{array}{l}0.532- \\
0.16\end{array}$ & 0.32 & 0.11 & $\begin{array}{l}110.74- \\
17.80\end{array}$ & 59.13 & 25.90 & $\begin{array}{l}101.68- \\
8.42\end{array}$ & 50.21 & 33.92 & $\begin{array}{l}4.06- \\
0.80\end{array}$ & 2.25 & 1.27 & $\begin{array}{l}1.16- \\
0.12\end{array}$ & 0.51 & 0.30 \\
\hline Dhenkanal & $\begin{array}{l}0.726- \\
0.17\end{array}$ & 0.36 & 0.17 & $\begin{array}{l}284.75- \\
51.84\end{array}$ & 84.59 & 51.62 & $\begin{array}{l}101.04- \\
37.88\end{array}$ & 65.64 & 21.52 & $\begin{array}{l}6.22- \\
0.90\end{array}$ & 2.69 & 1.66 & $\begin{array}{l}2.72- \\
0.5\end{array}$ & 0.94 & 0.55 \\
\hline Khurdha & $\begin{array}{l}0.270- \\
0.16\end{array}$ & 0.21 & 0.03 & $\begin{array}{l}169.3- \\
73.04\end{array}$ & 98.33 & 23.50 & $\begin{array}{l}56.64- \\
24.94\end{array}$ & 36.23 & 7.56 & $\begin{array}{l}3.02- \\
2.3\end{array}$ & 2.60 & 0.20 & $\begin{array}{l}2.46- \\
1.04\end{array}$ & 1.40 & 0.32 \\
\hline Puri & $\begin{array}{l}1.061- \\
0.3\end{array}$ & 0.67 & 0.24 & $\begin{array}{l}197.737- \\
34.43\end{array}$ & 116.60 & 50.28 & $\begin{array}{l}88.138- \\
15.78\end{array}$ & 43.90 & 18.25 & $\begin{array}{l}3.941- \\
1.33\end{array}$ & 2.77 & 0.83 & $\begin{array}{l}2.886- \\
0.36\end{array}$ & 1.33 & 0.55 \\
\hline Sambalpur & $\begin{array}{l}0.343- \\
0.13\end{array}$ & 0.22 & 0.07 & $\begin{array}{l}76.28- \\
11.68\end{array}$ & 38.79 & 19.72 & $\begin{array}{l}120.06- \\
9.28\end{array}$ & 27.65 & 25.08 & $\begin{array}{l}3.52- \\
0.3\end{array}$ & 1.10 & 0.72 & $\begin{array}{l}0.96- \\
0.14\end{array}$ & 0.37 & 0.23 \\
\hline
\end{tabular}


The present study was taken up to characterize the variability of the available soil nutrient status and the extent of deficiency or toxicity in different districts of Odisha to optimize the nutrient use in soils. It was observed that soils were mostly deficient in $\mathrm{Zn}(33.57 \%)$ and B (80\%), which underlines the need of $\mathrm{Zn}$ and $\mathrm{B}$ fertilizer application in order to enhance the crop productivity.

\section{References}

Athokpam, H., Wani, S.H., Kamei, D., Athokpam H.S., Nongthmaithem, J., Kumar, D., Singh, Y.K., Naorem, B.S., Devi, T.R. and Devi, L. (2013). Soil macro and micro-nutrient status of Senapati district, Manipur (India). African Journal of Agricultural Research. 8(39):4932-4936.

Athokpam, H.S., Singh, K.S., Chongtham, N, Devi, K.N., Singh, N.B., Sanatomba A. and Sharma, P.T. (2018). Vertical distribution of micronutrient cations in Imphal East and West district, Manipur (India). International Journal of Current Microbiology and Applied Sciences. 7(8): 4222-4227.

Athokpam, H.S., Zimik, V.S, Chongtham, N., Devi, K.N., Singh, N.B., Watham, L., Sharma, P.T. and Athokpam, H. (2016) Profile distribution micronutrient cations in citrus orchard of Ukhrul district, Manipur (India). International Journal of Agriculture, Environment and Biotechnology. 9(4): 691-697.

Das, J. and Talukdar, M.C. (2003) Available copper, manganese, iron and zinc in five different soil associations of Barpeta district of Assam. New Agriculturist 14, 23-25.

Gao, S., Yan, R., Cao, M., Yang, W., Wang, S. and Chen, F. 2008. Effect of on growth, antioxidant enzymes and phenylalanine ammonia-lyase activities in Jatropha curcasL. seedling. Plant, Soil and Environment. 54(3): 117-122.

Gupta, N., Trivedi, S.K., Bansali, K.N., Kaul, R.K. 2003. Vertical distribution of micronutrient cations in some soil series of north Madhya Pradesh. Journal of the Indian Society of Soil Science. 51: 517522.

Khanday, M.U.D.D., Ram, D., Wani, J.A. and Ali, T. 2017. Vertical distribution of nutrients of the soils of Namblan subcatchment of Jhelum basin of Srinagar district in Kashmir valley. International Journal of Current Microbiology and Applied Sciences. 6: 375-381.

Kumar, P., Sharma, S.P. and Sharma, P.O. (1996). Micronutrient status of different landforms of Soan River valley soils of lower Shiwaliks. Journal of the Indian Society of Soil Science. 44(2): 330-331.

Lindsay WL, Norvell WA. Development of DTPA soil tests for $\mathrm{Zn}, \mathrm{Fe}, \mathrm{Mn}$ and $\mathrm{Cu}$. Soil Science Society of America J. 1978; 42:421-428.

Page, A.L., Miller R.H. and Keeney D.R. (1982) Methods of Soil Analysis, Part 2: Chemical and Microbiological Properties. 2nd Edition. ASA and SSSA, Madison, Wisconsin.

Rengel, Z. (2007). Cycling of micronutrients in terrestrial ecosystems. In: Marschner, P. and Rengel, Z. (Eds.) Nutrient Cycling in Terrestrial Ecosystem. Springer- Verlag, Berlin, Heidelberg, pp. 93-121.

Sangwan, B.S. and Singh, K. (1993). Vertical distribution of $\mathrm{Zn}, \mathrm{Mn}, \mathrm{Cu}$ and $\mathrm{Fe}$ in the semi- arid soils of Haryana and their relationships with soil properties. Journal of the Indian Society of Soil Science. 41(3): 463-467.

Sarkar, D., Baruah, U., Gangopadhyay, S.K., Sahoo, A. K., Velayutham, M. (2002). Characteristics and classification of soils of Loktak catchment area of Manipur for sustainable land use 
planning. Journal of the Indian Society of Soil Science. 50(2): 196-204.

Satyavathi, P.L.A. and Reddy, M.S. (2004).

Distribution of DTPA extractable micronutrient in soils of Telangana, Andhra Pradesh. Agropedology. 14(1): 32-37.

Sen, T.K., Dubey, P.N., Maji, A.K. and Chamuah, G.S. (1997). Status of micronutrients in some dominant soils of Manipur. Journal of the Indian
Society of Soil Science. 45(2): 388-390. Singh, M.V. (2004). Micronutrient deficiencies in Indian soils and field usable practices for their correction. IFA International Conference on Micronutrients, New Delhi.

Verma, V.K., Setia, R.K., Sharma, P.K. (2007b). Distribution of micronutrient cations in different physiographic units of semi-arid region of Punjab. Agropedology. 18: 58-65.

\section{How to cite this article:}

Aurobindo Mohanta, Sai Parasar Das, Gourahari Santra and Debadatta Sethi. 2020. Status of Micronutrients in Different Districts of Odisha, India. Int.J.Curr.Microbiol.App.Sci. 9(07):

3980-3984 doi: https://doi.org/10.20546/ijcmas.2020.907.467 